\title{
RELATIONSHIP BETWEEN UPPER BODY STRENGTH AND PERFORMANCE AT CANOE FREESTYLE
}

\author{
Nina Csonková, Dušan Kutlík \\ Department of Outdoor sports and Swimming, Faculty of Physical Education and Sport, Comenius University \\ in Bratislava

\begin{abstract}
SUMMARY: Performance in all canoe disciplines is based on the physical condition of the paddler and his technique and mental ability to adapt to the racing condition. The strength belongs to the most important physical factors in canoe sprint and canoe slalom disciplines. We believed that in canoe freestyle the strength has an important role in relation to the performance in comparison to other canoe disciplines. The aim of this study was to identify the relationship between upper body strength and special canoe freestyle performance. The study group consisted of 16 senior kayak freestyle paddlers in the age group $26 \pm 3$ years old. Fitro Dyne Premium was device used to obtain data for analysis of the level of general upper body strength abilities. To determine special upper body strength we used tests on paddle machine and freestyle kayaking flat water tests. Freestyle performance was measured during ECA Euro Cup 2013 competition in Slovakia, Čunovo by official ICF judges. The data obtained were measured by the Spearman Correlation (r) correlation test. The results of the study show significant relations between kayak freestyle performance and test of general strength endurance $(p<0.05)$, special strength endurance, special dynamic strength $(p<0.01)$. There were no statistically significant correlations between kayak freestyle performance and general maximal power, dynamic strength, special maximal power.
\end{abstract}

Keywords: freestyle kayaking, upper body strength, performance, top senior athletes

DOI 10.1515/afepuc-2017-0006

(C) Acta Facultatis Educationis Physicae Universitatis Comenianae 


\section{Introducion}

Sport performance as a result of specific motion activities aimed at solving the tasks defined by the rules is the final manifestation of the internal integral in athletes that affect the effects of other external factors (Moravec 2007). According Dovalil (2002) Sport performance (as an inclination to repeatedly accomplish performance) is forming gradually and it is result of natural growth and development of the individual person, environmental impact and customs sport training. Increasing of performance has to be understood in a wider context.

By the structure of sport performance we mean to expediently arrange factors and relations between them. This strictly defined relations are internal condition of its functionality and its expediency resulting in bio-psycho-motoric preparedness for maximal performance in competition (Moravec 2007).

Motion abilities are considered as an individual internal assumption of human organism to motion activity where it is manifest itself. In the complex of human's assumption to motion activity we can differ following abilities: endurance, strength, speed, coordination and mobility (Perič 2010). The importance of strength abilities development in last years is accepting by most of the coaches in sport practice at all levels. Technical excellence and speed of execution of basic motion tasks is considered as a limited in many sports disciplines but to reach the optimal training effect with the aim of improving the sport performance is needed a certain level of strength abilities development. It is because of the direct relation with performance and preventing potential injury as well (Kampmiller 2007). Matouschek (2011) also wrote that a substantial reserve for further development of the performance in endurance sport, lies in the increase of the strength employment in single-sequence.

Every sport's discipline require certain abilities from athletes which are important for their success. Based on the definitions Szanto (2010) canoeing is a sport that requires coordinated action between the paddler (athlete), the paddle as the propulsion tool, the boat as the vehicle providing buoyancy and the water as the medium of transport. According to Caballero (2015) canoeing, as each sport, has its needs special force, which is why training methods have to be adapted to specific needs of this sport. Canoeing in still waters, could be considered as a resistance force sport. Nikonorov (2015) wrote strength development in canoeing is an integrated part of comprehensive training process, targeted to improve specific canoeing abilities and the effectiveness of training on the water. Efficiency of this integration in particular makes strength development in canoeing different to the other sports. 
Based on the definitions of European Canoe Association (ECA 2012) freestyle kayaking is a white water sport where the paddler performs a range of acrobatic tricks and manoeuvres on a river feature (artificial or natural) such as a wave or hole. International Canoe Federation (ICF 2015) defines canoe freestyle as a whitewater discipline where competitions take place on stationary river features which is named playspot. These can be breaking or partially breaking standing waves, holes and stoppers typically formed at the bottom of small drops or weirs where the water flows back on itself, or eddy lines on the boundary of slow moving water at the river edge and faster water. In ICF events, athletes have a set time to perform as many different moves as possible, scoring additional points for style. Finals are judged on three 45 second runs. Canoe freestyle is a constantly evolving discipline, with new tricks being developed to complement and improve on existing moves. These moves fall into three categories, entry moves, basic moves and bonuses, and are similar to those performed in freestyle snowboarding, surfing and skating. Spins, flips and turns are accompanied with names including roundhouse, donkey flip and mcnasty.

Sports performance, in terms of structure, characterize number and arrangement of factors. Halašová (2011) wrote that the level of special freestyle kayak skills is very important but big part has a development of condition, coordination and mental abilities. Special performance in freestyle kayaking is dependent on a number of factors. Because it is a sport performed in nature, in the first place, we can mention the changing natural conditions such as type of playspot, amount of water flow and its characteristic, water temperature. Furthermore, it is the level of paddling technique and condition and coordination skills.

We suppose strength abilities affect special kayak freestyle performance. The aim of the study is to identify the relationship between kayak freestyle performance and upper body strength. We assume to find significant relationship between special dynamic and endurance power.

Based on the previous analysis, following hypotheses were set up:

- there will be significant relationship between special dynamic power and sport performance

- there will be significant relationship between both, special and general strength endurance and sport performance

\section{Methods}

\section{Participants}


Monitored group consiste of 16 senior kayak freestyle paddlers in the age group $26 \pm$ 3 years whose ranking at the World Cup 2013 was top 30. The average body height was 178.8 $\pm 5.1 \mathrm{~cm}$, average body weight was $73.3 \pm 7.3 \mathrm{~kg}$, average sport age was $11 \pm 2.9$ years.

\section{General tests of strength abilities}

The devices used in testing strength abilities were Fitro Dyne Premium and computer, barbell, barbell discs. Fitro Dyne Premium is a computer system for assessment of strength capabilities and feedback monitoring of strength training. This device registers and displays basic biomechanical parameters involved with weight exercises. High reliability of Fitro Dyne Premium has been proven by studies of Jennings et al. (2005) and Fry et al. (2006).

The device for measuring Muscle performance (FitroDyne Premium) became commercially available and it is used in research and sport practice as well. This device is connected with traditionally fitness equipment and measures speed of muscle contraction. Muscle power is calculated from strength production and speed contraction (Vanderka 2013). These tests were carried out two days before euro cup event where the sport performance was measured.

To diagnose the level of strength abilities there were used following tests:

1. Bench pull test of maximal power. The aim of this test was to indicate maximal power and the weight of loads at maximal power. Subjects started at the weight of $50 \mathrm{~kg}$ and did three attempts after it the loads was increased of $5 \mathrm{~kg}$, subject did three more attempts and so on. This continued until subject reached maximal power.

2. Bench pull test of endurance strength. Subject performed the exercise with the $66 \%$ weight of his body mass. The task was to do the maximum of repetitions during the 30 seconds. Examiner had to watch out if the each attempt was provided right. Only attempt when the weight touch the bench was counted. Starting position was from stretched out arms.

3. Pull bench test of dynamic strength. Subject perform exercise with weight of maximum performance until his power starts to drop. It's about 10 - 12 repeats. Subject have to do each pull as quickly as possible, between each attempt can be a pause. The result is the number of attempts with power not below $80 \%$ of maximal performance.

\section{Special tests of strength abilities}

Test of special strength abilities were selected on base of years of experts experiences in freestyle kayaking. Test were provided on paddle machine Dansprint and on freestyle kayaks at swimming pool.

4. Test of maximal power. To determine specific maximal power we used paddle machine Dansprint. Subject start to paddle at the level of 60 Wats and the resistance of 5, 
every 10 seconds the power is increased of 20 Wats. This continues until subject reach the maximal power.

5. Test of special strength endurance. This test was provided at swimming pool on freestyle kayaks. The task of subject was to execute as much as possible cartwheels. Cartwheels are two consecutive ends in the same rotational direction, and both ends at a vertical angle between $45^{\circ}$ and $100^{\circ}$ (canoeicf.com 2015). Execution of attempts was evaluated by ICF Judges.

6. Test of special dynamic strength. This test was provided at swimming pool on freestyle kayaks. The task for subject was to execute 12 air loops. Air loop is a front flip initiated and finished between a horizontal angle of $-20^{\circ}$ and $20^{\circ}$, landing in the hole or in the wave, move is performed with the boat not touching the water at one time of the execution of the move. (canoeicf.com 2015). The aim was to keep boat in each attempt during rotating as high as possible. The result is the number of attempts, where the boat reach at least $80 \%$ of maximal boat's distance from water level. To measure boat's distance from water level we created digital scale. All attempts were observed with 150 frame rate video camera. Computer displays whole movement where we can see the highest point of boat and the score on scale.

\section{Sport performance}

Kayak freestyle performance is evaluated by points. Kayakers perform freestyle ride in playspot, which can be hole or wave and judges give them points for their moves. Freestyle ride consist of various moves, only finished move is scored. The ride lasts 45 seconds. The special kayak freestyle performance for our study was measured during ECA Euro Cup competition in Slovakia, Čunovo by three official ICF judge. The score of best placed ride was counted.

\section{Data analysis}

For data analysis we used descriptive statistics (arithmetical average, median, standard deviation, minimum and maximum value). As a data processing method to clarify the relationship between the monitored variables we used Spearman's correlation coefficient. The statistical significance is at level of $1 \%$ and $5 \%$.

\section{Results and discussion}

Table 1 show us subject's data of monitored parameters. The output of the relational analysis using Spearman Correlation between variables is showed in Table 2. The notable relationship of direct correlation at the $1 \%$ level of statistical significance is found between 
special kayak freestyle performance and tests of special endurance strength and special dynamic strength. Spearman correlation analysis also revealed relationship between special freestyle kayak performance and general endurance strength test at the $5 \%$ level of statistical significance.

\section{Table 1}

Data of monitored parameters

\begin{tabular}{|c|c|c|c|c|c|c|c|c|c|}
\hline & \multicolumn{4}{|c|}{ General upper body strength } & \multicolumn{4}{|c|}{ Special upper body strength } & \multirow{2}{*}{$\begin{array}{c}\text { Sport } \\
\text { Performance } \\
\text { [points] }\end{array}$} \\
\hline & T1 [W] & $\begin{array}{c}\text { T1' } \\
{[\mathrm{W} / \mathrm{kg}]}\end{array}$ & $\begin{array}{l}\text { T2 } \\
\text { (n) }\end{array}$ & $\begin{array}{l}\text { T3 } \\
\text { (n) }\end{array}$ & $\begin{array}{c}\text { T4 } \\
{[\mathbf{W}]}\end{array}$ & $\begin{array}{l}\text { T5 } \\
\text { (n) }\end{array}$ & $\begin{array}{l}\text { T6 } \\
\text { (n) }\end{array}$ & $\begin{array}{c}\text { T6' } \\
{[\mathrm{cm}]}\end{array}$ & \\
\hline $\mathbf{A V}$ & 564.7 & 7.5 & 29.8 & 8 & 163.6 & 12.6 & 7 & 46.5 & 1214 \\
\hline Me. & 572.4 & 7.6 & 27.5 & 8 & 159 & 12.5 & 7 & 47.5 & 1301.5 \\
\hline SD & 86.2 & 0.8 & 7.3 & 1.6 & 25.8 & 2.6 & 1.7 & 5.7 & 319.7 \\
\hline Min. & 416.7 & 5.7 & 20 & 5 & 129 & 8 & 4 & 34 & 652 \\
\hline Max. & 700.1 & 8.6 & 45 & 11 & 203 & 16 & 10 & 52 & 1678 \\
\hline
\end{tabular}

Notes: $A V$ - arithmetical average; Me - median; SD - standard deviation; Min - minimum; Max - maximum; T1 - bench pull max.P (W); T1' - bench pull max. P/m (W/kg); T2 - bench pull max. of repeats per $30 \mathrm{sec}$. with $66 \%$ of body weight, T3 - pull bench with weight of max. performance; T4 - paddle machine max.P; T5 - cartwheels in 30 s.; T6 - air loops; T6'-distance from water level to boat of best attempt

Table 2

Relationship between kayak freestyle performance and upper body strength

\begin{tabular}{|c|c|c|c|c|c|c|c|c|}
\hline & $\begin{array}{c}\text { T1 } \\
{[\mathbf{W}]}\end{array}$ & $\begin{array}{c}\text { T1' } \\
{[\mathrm{W} / \mathrm{kg}]}\end{array}$ & $\begin{array}{l}\text { T2 } \\
\text { (n) }\end{array}$ & $\begin{array}{l}\text { T3 } \\
\text { (n) }\end{array}$ & $\begin{array}{c}\text { T4 } \\
{[\mathbf{W}]}\end{array}$ & $\begin{array}{l}\text { T5 } \\
\text { (n) }\end{array}$ & $\begin{array}{l}\text { T6 } \\
\text { (n) }\end{array}$ & $\begin{array}{c}\text { T6' } \\
{[\mathrm{cm}]}\end{array}$ \\
\hline $\begin{array}{l}\text { kayak free- } \\
\text { style per- } \\
\text { formance }\end{array}$ & $\begin{array}{c}r= \\
0.22\end{array}$ & $\begin{array}{c}r= \\
0.45\end{array}$ & $\begin{array}{c}\mathrm{r}= \\
0.51 \\
*\end{array}$ & $\begin{array}{c}r= \\
0.06\end{array}$ & $\begin{array}{c}r= \\
0.27\end{array}$ & $\begin{array}{c}\mathrm{r}= \\
0.86^{* *}\end{array}$ & $\begin{array}{c}r= \\
0.85^{* *}\end{array}$ & $\begin{array}{c}\mathrm{r}= \\
0,79 * *\end{array}$ \\
\hline
\end{tabular}

Notes: level of significance $* * p<0,01 ; * p<0,05$

According Szanto (2010) strength endurance is very foundation of the repetitive action of paddle-sport as it determines the athlete's ability to apply adequate strength during each stroke but at the same time resist fatigue. It is also vital that the force applied on each stroke 
should not diminish during races or training sessions. Strength endurance development is one of the basic task for all athletes in paddle-sport. We can confirm that the claims of Szanto (2015) about strength endurance are valid for kayak freestyle as well. In case of kayak freestyle performance it is a short term strength endurance while typical duration of competition ride is 45 seconds. It is categorized as an anaerobic endurance. High level of strength endurance secure good resistance of the organism to sustained high intensity work, better adaptation of the circulatory system and increase the capacity of the athlete to resist fatigue. Founded significant relationship between general strength endurance $(p<0.05)$ and special strength endurance $(\mathrm{p}<0.01)$ show us the importance of strength endurance development in freestyle kayaking.

Dynamic strength is needed to accelerate the boat and paddle at a high stroke rate. Dynamic strength is indispensable for specialists, and extremely important for kayak and canoe competitors (Szanto 2010). This is valid not only for canoe sprint and canoe slalom but for freestyle kayaking as we prove it in our research.

According Caballero (2015) training in water is after all, the most effective way to train canoeing. It is advisable that the higher categories (from age 16) get into the water regularly throughout an entire year. In case of not being able to enter the water, it is advisable to use alternative means such as training rafts or ergometer.

Relationship between special kayak freestyle performance and tests of general and specific maximal power and general dynamic strength is not statistically significant. Therefor we can't say chosen strength abilities measured by tests are significantly limiting factors for success in kayak freestyle special performance.

The difference in results in importance of power and dynamic strength in freestyle kayaking to compare with other canoe disciplines can be caused by various factors. First of all we have to mention the sport performance of freestyle kayaking which is based mainly on coordination abilities. As another factor we can mention the difference in the trainings program. While sprint and slalom canoeists use both, general and specific training methods, freestyle paddlers train mainly in water. This cause that our subjects didn't have that good technical skill to perform tests.

Any of the available studies from canoeing, did not look to the relationships between kayak freestyle performance and motion abilities. We see the importance of attention in performance in kayak freestyle through similar studies.

\section{Conslussion}


The present study is the first to investigate the relationships between kayak freestyle performance and strength abilities of top athletes. This paper presents the findings of mutual relationships between kayak freestyle performance and the level of selected strength abilities - general and special strength endurance, special dynamic strength.

Taking into account the results of our research, we recommended:

- increase general strength endurance, especially during winter training season,

- focus on special strength endurance on the water - specific conditions,

- develop special dynamic strength on the water-specific conditions,

- carry out further studies that would let us clarify the factors determining the structure of sport performance,

- apply further study to a larger number of subjects.

Our study present research results which can serve as a quality source of information for further research on structure of special performance.

\section{References}

1. CABALLERO, J.D. et al., 2015. Canoeist training in Germany from the base to the high level. In: FOLGAR, M. I. Training sprint in canoeing. Spain, pp. 102,106, 108. ISBN: 978-84-943815-7-7.

2. DOVALIL, J. et al., 2002. Kondiční príprava. In: DOVALIL, J. et al. Výkon a tréning ve sportu. Praha: Olympia, pp. 22-23. ISBN 80-7033-760-5.

3. ECA, 2012. Testing stamina and rapid manoeuvring [online]. 2012 [cit. 2017-01-12]. Accessible from: http://www.canoe-europe.org/index.php/component/content/article/8$\underline{\text { web/87-freestyle }}$

4. FRY, A. C., B. K. SCHILling \& L. W. WEISS, 2006. $\beta 2$ - Adrenergic Receptor Downregulation and Performance Decrements during High-intensity Resistance Exercise Overtraining. In: Journal of Applied Physiology. 101(6): 1664-1672.

5. HALAŠOVÁ, N., 2011. Teória kanoistickej discipliny kajak freestyle a didaktika jej základných figúr. Bratislava. Comenius University in Bratislava. Master thesis. Faculty of Physical Education and Sports, Department of Outdoor sports and Swimming.

6. ICF, 2015. What is Canoe Freestyle? [online]. 2015 [cit. 2017-01-12]. Accessible from: http://www.canoeicf.com/discipline/canoe-freestyle

7. ICF, 2015. Appendix 1 - Basic Moves List-Surface Boat [online]. 2015 [cit. 2017-0112]. Accessible from: http://www.canoeicf.com/sites/default/files/appendixes _moves_and_bonuses_220315.pdf 
8. JENNINGS, C. L., W. VILJOEN, J. DURANDT \& M. LAMBERT, 2005. The Reliability of the FitroDyne as a Measure of Muscle Power. In: The Journal of Strength Conditioning Research. 19(4): 859-863.

9. KAMPMILLER, T \& M, VANDERKA, 2007. Silové schopnosti a ich rozvoj. In: Teória a didaktika výkonnostného a vrcholového športu. Bratislava: ICM AGENCY, pp. 88-89. ISBN 978-80-89075-31-7.

10. MATUSCHEK, R., 2011. The meaning of the conditional abilities. In: Performance and theory of canoe training. Lausanne: ICF. ISBN 978-960- 99730-0-7.

11. MORAVEC, R. et al., 2007. Teória športového výkonu. In: Teória a didaktika výkonnostného a vrcholového športu. Bratislava: ICM AGENCY. ISBN 978-80-8907531-7.

12. NIKONOROV, A. et al., 2015. Power development in sprint canoeing. In : Training sprint in canoeing. Spain. ISBN: 978-84-943815-7-7.

13. PERIČ, T \& J. DOVALIL, 2010. Sportovní trénink. Praha: Grada Publishing. ISBN 978$80-247-2118-7$.

14. SZANTO, C., 2010. Canoe Sprint, Lausanne: International Canoe Federation.

15. VANDERKA, M., 2013. Silový tréning pre výkon. Bratislava: Slovenská vedecká spoločnost' pre telesnú výchovu a šport. ISBN 978-80-89075-40-9 